\title{
Pre And Postoperative Use of Force Platform in Hallux Valgus Surgery-Case Report
}

\author{
Groseanu Florin ${ }^{1,2 *}$ and Cristea Stefan ${ }^{1,2}$ \\ ${ }^{1}$ University of Medicine and Pharmacy Carol Davila, Romania \\ ${ }^{2}$ St. Pantelimon Emergency Hospital, Romania
}

Submission: June 25,2019; Published: July 11, 2019

*Corresponding author: Groseanu Florin, University of Medicine and Pharmacy Carol Davila, St. Pantelimon Emergency Hospital, Sos. Pantelimon 340, Sector 2, Bucharest, Romania

\begin{abstract}
We tried to analyze the importance of information's obtained using a force platform in objective functional assessment of Scarf osteotomy in hallux valgus surgery. The aim was to obtain a normal architecture of the foot by restoring the normal relations of the first ray and the mobility in the first metatarso-phalangeal articulation. We used the AMTI Accu Gate force platform to analyze pre and postoperative force reaction of the foot succeeding Scarf osteotomy of the first metatarsal. Using the Scarf technique, we were able to restore the normal alignment of the forefoot. Data from the force platform revealed modifications of force reaction components of both leg in contrast with the pedobarographic studies. So, it is important that the technique chosen for correction should reestablish the normal parameters in all 3 space planes.
\end{abstract}

Keywords: Force platform; Scarf; Hallux valgus

\section{Introduction}

Medical literature considering surgery of the important static deformities of the foot present pressure distribution analysis on foot-ground interface [1-3]. We tried to analyze the importance of informations obtained using a force platform in objective functional assessment of Scarf osteotomy in hallux valgus surgery.

\section{Case Report}

We present the case of a 57-years old male patient presenting left hallux valgus grade II and second hammer toe. Clinical exam revealed pain at first metatarso-phalangeal articulation, presence of exostosis on the medial aspect, first phalange of the hallux in valgus and pronated, the distal phalange under the second toe, presence of dorsal dislocation of the metatarsophalangeal articulation of the second toe, limited mobility of the first toe (flexion $5^{\circ}$, extension $10^{\circ}$ ).

To correct the deformity, we used the Scarf technique consisting in exostosectomy, lateral arthrolyse, Z osteotomy of the first metatarsal and osteosynthesis with two screws. The aim was to obtain a normal architecture of the foot by restoring the normal relations of the first ray and the mobility in the first metatarso-phalangeal articulation (flexion $20^{\circ}$, extension $40^{\circ}$ ).

We used the AMTI AccuGate force platform to analyze pre and postoperative force reaction of the foot succeeding Scarf osteotomy of the first metatarsal. The technique consisted in 2 session of measuring the ground reaction force: vertical (Fz), medio-lateral (Fy) and sagittal (Fx); the first session was done 5 weeks before surgery and the second session at 6 weeks postoperative. Every session consisted in 2 phases of 10 valid successive walking on the force platform with the same leg and the same direction of walking.

\section{Results}

Using the Scarf technique, we were able to restore the normal alignment of the forefoot: metatarso-phalangeal angle of $10^{\circ}$, Varus of the first metatarsal of $10^{\circ}$, distal articular angle of the first metatarsal of $0^{\circ}$ and the attack angle of the first metatarsal of $20^{\circ}$. The osteotomy was consolidated at 6 weeks.

We eliminated the aberrant values using the Romanovski test. Testing of the values normality was done using KolmogorovSmirnov test; the null hypothesis "distribution is not normal" was rejected for all data series. The analysis revealed significant postoperative lengthening of center of pressure trajectory for both the left and the right foot. Significant differences (PairedSamples $\mathrm{T}$ Tests, $\mathrm{p}<0,05)$ were obtained for the left foot $(\mathrm{Fz}-$ $\mathrm{p}=0,047$; duration of stance phase- $\mathrm{p}=0,000)$ and the right foot (Fz-p=0,011; Fx-p=0,030; Fy-p=0,023; duration of stance phase- $p=0,000$ ) Table 1 . Data from the force platform revealed modifications of force reaction components of both leg in contrast with the pedobarographic studies. 
Table 1: Results of force reactions using the force platform.

\begin{tabular}{|c|c|c|c|c|}
\hline \multirow{2}{*}{ Foot } & Condition & Fx Value (\%) & Fy Value (\%) & Fz Value (\%) \\
\hline \multirow{3}{*}{ Left } & Preoperative & 13,6 & 6,12 & 102,25 \\
\cline { 2 - 5 } & Postoperative & 12,52 & 5,87 & 98,14 \\
\cline { 2 - 5 } & Difference & $1,08(-7,9 \%)$ & $0,25(-4,09 \%)$ & $4,11(-4 \%)$ \\
\hline \multirow{3}{*}{ Right } & Preoperative & 13,36 & 8,06 & 100,33 \\
\cline { 2 - 5 } & Postoperative & 11,14 & 3,98 & 104,55 \\
\cline { 2 - 5 } & Difference & $12,22(-16,6 \%)$ & $4,08(-50,6 \%)$ & $4,22(+4,2 \%)$ \\
\hline
\end{tabular}

\section{Discussion}

Although in the past walking was considered symmetric for both feet, in the present Viel [4] showed that there is an asymmetry in the parameters of the 2 feet, corresponding to the "propulsion foot" (the dominant one) and "amortization foot". Gagey and Weber [5] established the value of the normal parameters of the feet on studies for the variation of center of pressure in time, but the data bases are incomplete for this time, so more studies are needed. In our case we have succeeded to restore the normal position of this center. Our data suggest that in hallux valgus there are modifications of kinematic parameters of the foot not only on the vertical plane (Fz), but also in anteroposterior ( Fx) and lateral planes (Fy). So, it is important that the technique chosen for correction should reestablish the normal parameters in all 3 planes. In our case the correction obtained with Scarf technique was appropriate.

The purpose of the surgical treatment is to obtain a Greek foot and the metatarsal should be lined up according to Maestro [6] criteria. But it is mandatory to reestablish the normal trajectory of the center of pressure, as showed in our study using the force platform. So, we think that in the future orthopaedic surgeons should use data obtained from these platforms to increase their skills and to realize a better correction of forefoot deformities.

\section{Conflict of Interest}

The authors declare no financial interest or any conflict of interest.

\section{References}

1. Costa JM (2010) Modified Chevron osteotomy: preliminary analysis of baropodometric behavior. Acta ortop bras 18(4): 191-196.

2. Borton DC, Stephens MM (1994) Basal metatarsal osteotomy for hallux valgus. J Bone Joint Surg Br 76(2): 204-209.

3. Jones $S$ (2004) Scarf osteotomy for hallux valgus. A prospective clinical and pedobarographic study. J Bone Joint Surg Br 86(6): 830-836.

4. Viel E, Perelle A, Peyranne J, Esnault JM (1985) M Med Chir Pied 2: 151160.

5. Gagey PM, Weber B (1995) Posturologie. Régulation et dérèglements de la station debout. Masson, Paris. pp. 1-145.

6. Maestro M (1997) Biomécanique et repères radiologique du sésamoïde latéral de l'hallux par rapport à la palette métatarienne. Méd Chir Pied Expansion scient fique française 11(3): 145-154.

\section{Your next submission with Juniper Publishers will reach you the below assets}

- Quality Editorial service

- Swift Peer Review

- Reprints availability

- E-prints Service

- Manuscript Podcast for convenient understanding

- Global attainment for your research

- Manuscript accessibility in different formats ( Pdf, E-pub, Full Text, Audio)

- Unceasing customer service

Track the below URL for one-step submission https://juniperpublishers.com/online-submission.php 